\title{
THE USE OF REMOTE SENSING IN ARABLE LAND IDENTIFICATION AND MAPPING
}

\author{
Bojan Popović', Dušan Jovanović \\ Received: November 15, 2017 | Accepted: December 10, 2017
}

\begin{abstract}
Satellite images have a wide application for detection and identification of objects, phenomena and changes on the surface of the Earth. In this paper are presented methods for arable land identification based on Sentinel-2 satellite imagery and distribution of the obtained data. The images were atmospherically corrected, resulting in the true reflection values from the ground. The identification procedure is based on known annual crops land cover variation rules during seasons. The vegetation signal in the images was enhanced using the SAVI vegetation index, after which the detection of arable land was carried out by raster subtraction. As a result, data on the spatial distribution of 5 arable land classes were obtained: summer crops, winter crops, pastures, vineyards and orchards and unclassified land. In order to complete the final result, inhabited places and water surfaces were detected and mapped. The resulting data were vectorized and displayed through a three-layer GIS (Geographic information system) service-based architecture in accordance with OGC specification.
\end{abstract}

Key words: remote sensing, Sentinel-2, vegetation indices, arable land, GIS

\section{INTRODUCTION}

Arable land (Latin arabilis, "able to be plowed") is, according to one definition, land capable of being ploughed and used to grow crops. Remote sensing is used as one of the basic methods for arable land identification. Remote sensing is acquisition of information about an object or phenomenon through systems that are not in direct physical contact with the investigated object (sensors on an airplane, satellite) (Regodić, 2008). This paper deals with the use of Sentinel-2 satellite images for identifying and mapping arable land and distribution of the obtained results through a GIS three-layer architecture. Municipalities of Novi Bečej and Žabalj were chosen as areas of interest. Various software tools were used for pre-processing, analysis, data extraction, presentation and data distribution.

\footnotetext{
Geodesy and Geomatics, Faculty of Technical Sciences, University of Novi Sad, bojanpop94@gmail.com Computing and Control Engineering, Faculty of Technical Sciences, University of Novi Sad, dusanbuk@uns.ac.rs
} 


\section{MATERIALS AND METHODS}

Sentinel-2 images were downloaded from the Copernicus Open Access Hub for the area of municipalities Novi Bečej and Žabalj in 2016. Sentinel-2 satellites use MSI sensor that measures reflected energy in 13 spectral bands with a spatial resolution of 10,20 and 60 meters (Drusch et al., 2012). The images were atmospherically corrected in Sen2Cor software in order to get the true reflection value from the ground. A dark object subtraction method is used, which assumes that the pixel with the lowest value in each band should be equal to zero, and that its radiometric value is actually the result of aggregate atmospheric errors (Chavez, 1988) (Jovanović et al, 2016). B2 (Blue), B3 (Green), B4 (Red) and B8 (NIR) bands were selected and merged into one raster. The images were cut to the shape of municipalities.

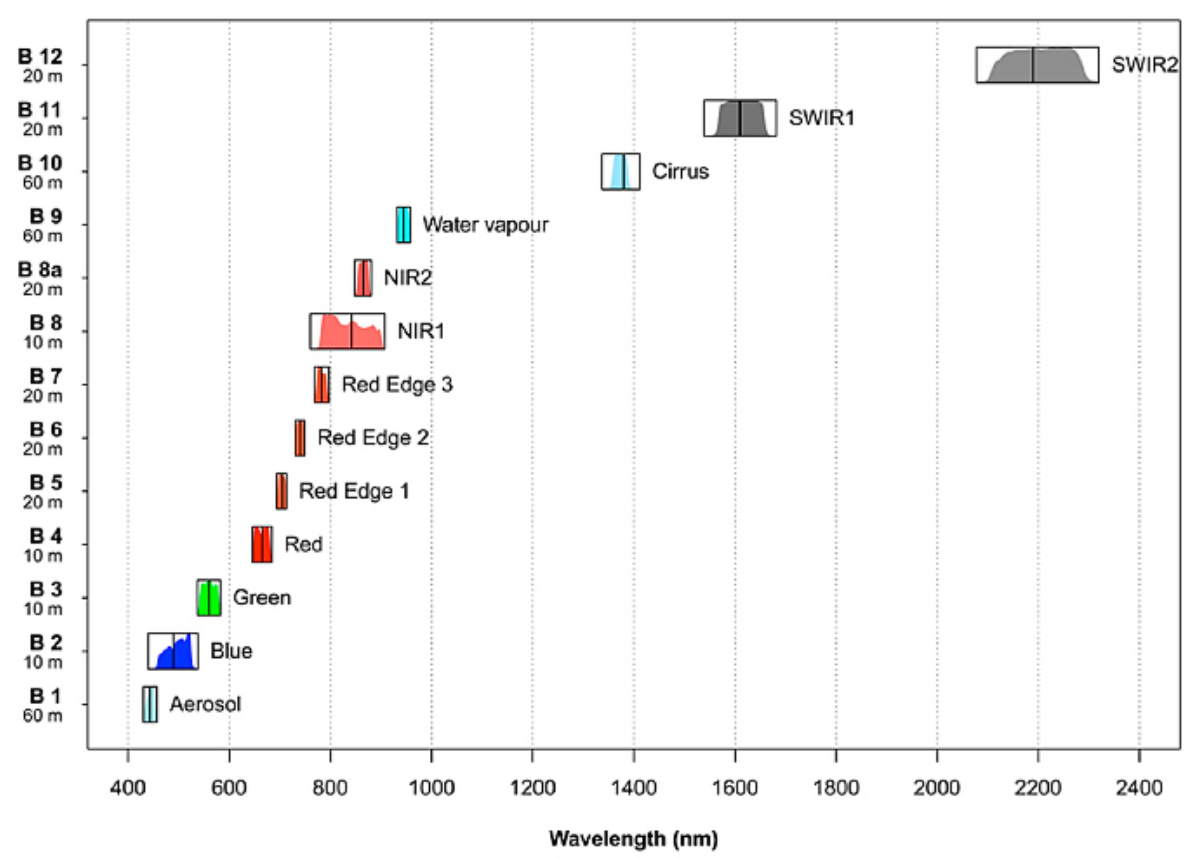

Figure 1. Sentinel-2 bands 

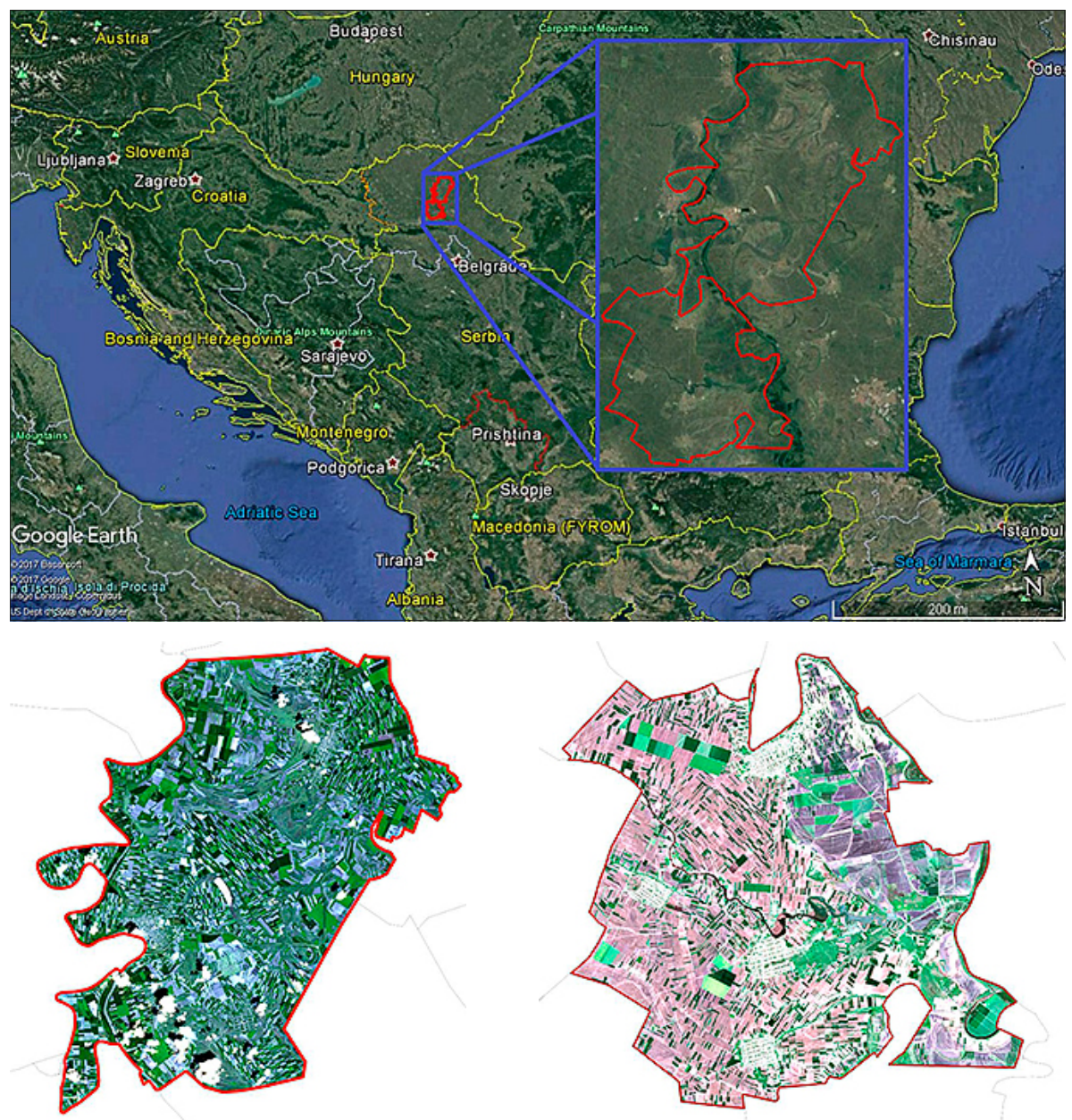

Figure 2. Sliced images

\section{SAVI AND CLASSIFICATION}

In areas where vegetative cover is low $(<40 \%)$ and the soil surface is exposed, the reflectance of light in the red and near-infrared spectra can influence vegetation index values. This is especially problematic when comparing different soil types that may reflect different amounts of light in the red and near infrared wavelengths. SAVI was developed as a modification of the NDVI to correct the influence of soil brightness when vegetative cover is low (Huete, 1988).

$$
\text { SAVI }=\frac{(1+\mathrm{L})(\text { NIR-Red })}{(\text { NIR }+ \text { Red }+ \text { L })}
$$

Equation 1. SAVI index 
where:

- NIR - reflectance value of the near infrared band;

- Red - reflectance of the red band;

- L - soil brightness correction factor. The value of $\mathrm{L}$ varies by the amount or cover of green vegetation: in very high vegetation regions, $\mathrm{L}=0$; and in areas with no green vegetation, $\mathrm{L}=1$. Generally, an $\mathrm{L}=0.5$ works well in most situations.

SAVI index was applied on images from April and June, because those images were used in the process of identification. Next step was classification. For the purpose of this paper the classification was done into two classes: vegetation and soil. The whole procedure was done in the Erdas Imagine software. The images obtained as a result of the SAVI index were classified, so that all pixels with values from 0 to 0.9 were classified into the soil, and pixels with values higher than 0.9 into the vegetation.

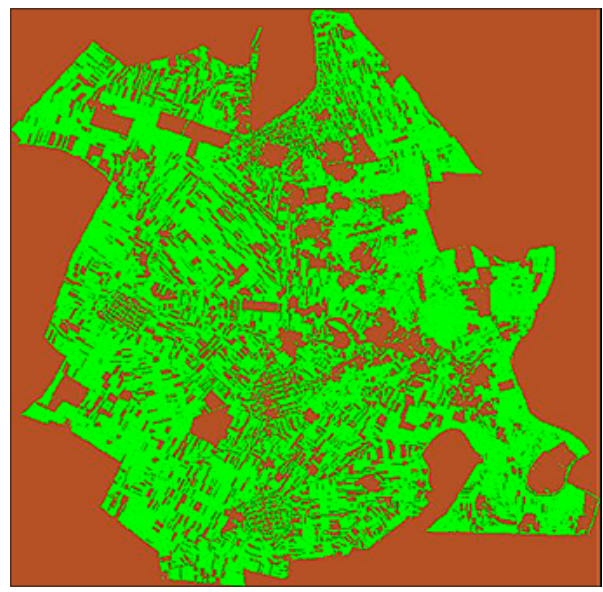

Figure 3. Classification result

\section{CHANGE DETECTION}

The principle on which this paper is based is that arable land, in most cases, is land with summer and winter crops planted on it. The summer crops are planted before summer, and then on those parcels is bare land without vegetation, while the winter crops have grown. In the fall, the situation is opposite. According to annual crops rules, two images were selected, one with the acquisition date of 07.04.2016. and the second 29.06.2016. Then the two rasters were subtracted: raster $_{\text {Jun }}-$ raster $_{\text {April. }}$ Since the pixels in the classified raster had values: 2 (pixels classified as vegetation) and 1 (pixels classified as soil), the pixels in the new raster that resulted from the subtraction can have 3 potential values:

- -1 winter crops (vegetation was there in April but not in June);

- 0 without change;

- 1 summer crops (vegetation was not there in April but was in June). 


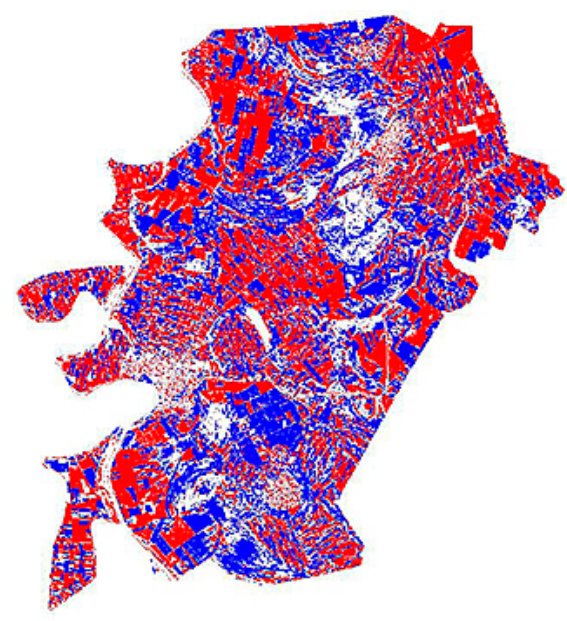

Figure 4. Result of raster subtraction

In the areas where the change occurred, pixels have value 1 or -1 so all pixels with value 0 can be ignored. The results are shown in the picture above with winter crops shown in blue and summer crops in red color.

\section{VECTORIZATION AND DATA PROCESSING}

In order to process the data, raster with the results was vectorized. For the purpose of easier data management, winter and summer crops were vectorized into separate files. Further processing was continued in the QGIS, where errors in polygon geometry were corrected due to clouds over the area. Polygons of unusual shapes were examined and, if
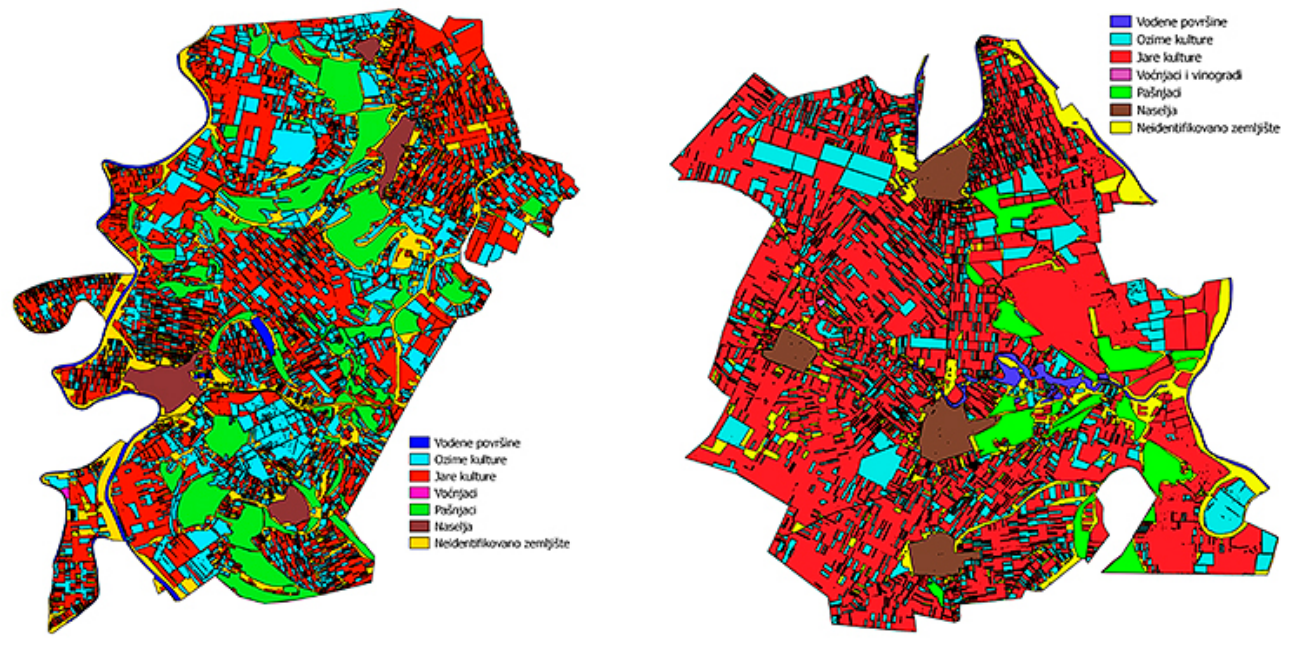

Figure 5. Final classification 
necessary, erased or corrected. Since there is no automatic identification method for orchards, vineyards and pastures, identification of these areas has been manually conducted with images from different periods.

Table 1. Numerical data

\begin{tabular}{|l|c|c|}
\hline Soil type & $\begin{array}{c}\text { Novi Bečej } \\
\text { Area }\left[\mathrm{km}^{2}\right]\end{array}$ & $\begin{array}{c}\text { Žabalj } \\
\text { Area }\left[\mathrm{km}^{2}\right]\end{array}$ \\
\hline Summer crops & 217,885 & 231,804 \\
\hline Winter crops & 158,124 & 67,856 \\
\hline Orchards and vineyards & 0,242 & 0,091 \\
\hline Pastures & 81,949 & 18,995 \\
\hline
\end{tabular}

\section{DATA DISTRIBUTION THROUGH THE GEOPORTAL AND CESIUM}

Data distribution was done through a three-layer GIS service-oriented architecture. Vector data obtained in the previous step were loaded into the PostGIS database (Sladić et al, 2014).

\begin{tabular}{|c|c|c|c|c|c|c|c|c|c|}
\hline \begin{tabular}{|l|} 
gid \\
{$[\mathrm{PK}]$ integer }
\end{tabular} & $\begin{array}{l}\text { value } \\
\text { double precision }\end{array}$ & $\begin{array}{l}\text { class_name } \\
\text { character varying(128) }\end{array}$ & $\begin{array}{l}\text { red } \\
\text { double precision }\end{array}$ & \begin{tabular}{|l|} 
green \\
double precision
\end{tabular} & $\begin{array}{l}\text { blue } \\
\text { double precision }\end{array}$ & \begin{tabular}{|l|} 
opacity \\
double precision
\end{tabular} & $\begin{array}{l}\text { hypothesis } \\
\text { double precision }\end{array}$ & \begin{tabular}{|l|} 
area \\
numeric $(10,0)$
\end{tabular} & $\begin{array}{l}\text { geom } \\
\text { geometry(MultiPolygon,31277) }\end{array}$ \\
\hline 1 & 1 & vegetacija jul & 1 & 0 & 0 & 1 & 1 & 86163 & \\
\hline 2 & 1 & vegetacija jul & 1 & 0 & 0 & 1 & 1 & 12736888 & \\
\hline 3 & 1 & vegetacija jul & 1 & 0 & 0 & 1 & 1 & 40050 & $01060000202 \mathrm{D} 7 \mathrm{~A} 0000010000$ \\
\hline 4 & 1 & vegetacija jul & 1 & 0 & 0 & 1 & 1 & 2162338 & \\
\hline 5 & 1 & vegetacija jul & 1 & 0 & 0 & 1 & 1 & 11113 & $01060000202 D 7 \times 0000010000$ \\
\hline 6 & 1 & vegetacija jul & 1 & 0 & 0 & 1 & 1 & 67900 & $01060000202 D 7 R 0000010000$ \\
\hline 7 & 1 & vegetacija jul & 1 & 0 & 0 & 1 & 1 & 52738 & \\
\hline 8 & 1 & vogetacija jul & 1 & 0 & 0 & 1 & 1 & 103450 & \\
\hline 9 & 1 & vegetacija jul & 1 & 0 & 0 & 1 & 1 & 52425 & $01060000202 \mathrm{D} 7 \mathrm{x} 0000010000$ \\
\hline 10 & 1 & vegetacija jul & 1 & 0 & 0 & 1 & 1 & 37550 & $0106000020207 \mathrm{~A} 0000010000$ \\
\hline 11 & 1 & vegetacija jul & 1 & 0 & 0 & 1 & 1 & 901261 & \\
\hline 12 & 1 & vegetacija jul & 1 & 0 & 0 & 1 & 1 & 13663 & $01060000202 D 7 A 0000010000$ \\
\hline 13 & 1 & vegetacija jul & 1 & 0 & 0 & 1 & 1 & 34163 & \\
\hline 14 & 1 & vegetacija jul & 1 & 0 & 0 & 1 & 1 & 51725 & \\
\hline 15 & 1 & vegetacija jul & 1 & 0 & 0 & 1 & 1 & 14613 & $01060000202 \mathrm{D} 7 \mathrm{~A} 0000010000$ \\
\hline 16 & 1 & vogetacija jul & 1 & 0 & 0 & 1 & 1 & 37675 & $01060000202 D 7 A 0000010000$ \\
\hline 17 & 1 & vegetacija jul & 1 & 0 & 0 & 1 & 1 & 13800 & $01060000202 D 7 \times 0000010000$ \\
\hline 18 & 1 & vegetacija jul & 1 & 0 & 0 & 1 & 1 & 20088 & $01060000202 D 7 A 0000010000$ \\
\hline 19 & 1 & vegetacija jul & 1 & 0 & 0 & 1 & 1 & 11888 & $01060000202 D 7 A 0000010000$ \\
\hline 20 & 1 & vegetacija jul & 1 & 0 & 0 & 1 & 1 & 15400 & $01060000202 D 7 A 0000010000$ \\
\hline 21 & 1 & vegetacija jul & 1 & 0 & 0 & 1 & 1 & 88125 & $01060000202 D 7 A 0000010000$ \\
\hline 22 & 1 & vegetacija jul & 1 & 0 & 0 & 1 & 1 & 51113 & \\
\hline 23 & 1 & vegetacija jul & 1 & 0 & 0 & 1 & 1 & 890338 & \\
\hline 24 & 1 & vegetacija jul & 1 & 0 & 0 & 1 & 1 & 94888 & \\
\hline 25 & 1 & vogotacija jul & 1 & 0 & 0 & 1 & 1 & 9175 & $01060000202 \mathrm{D} 7 \mathrm{~A} 0000010000$ \\
\hline 26 & 1 & vegetacija jul & 1 & 0 & 0 & 1 & 1 & 88750 & \\
\hline 27 & 1 & vegetacija jul & 1 & 0 & 0 & 1 & 1 & 26713 & $01060000202 D 7 A 0000010000$ \\
\hline 28 & 1 & vegetacija jul & 1 & 0 & 0 & 1 & 1 & 329575 & \\
\hline
\end{tabular}

Figure 6. Database

Data from PostGIS were published on Geoserver where they were assigned with the appropriate styles using SLD (Styled Layer Descriptor).

In the Apache Tomcat environment, OpenLayers and Cesium geoportals were formed using HTML and JavaScript programming languages. In Geoserver, OGC services were created, where WFS (Web Feature Service) is used for presentation and distribution of obtained data. 


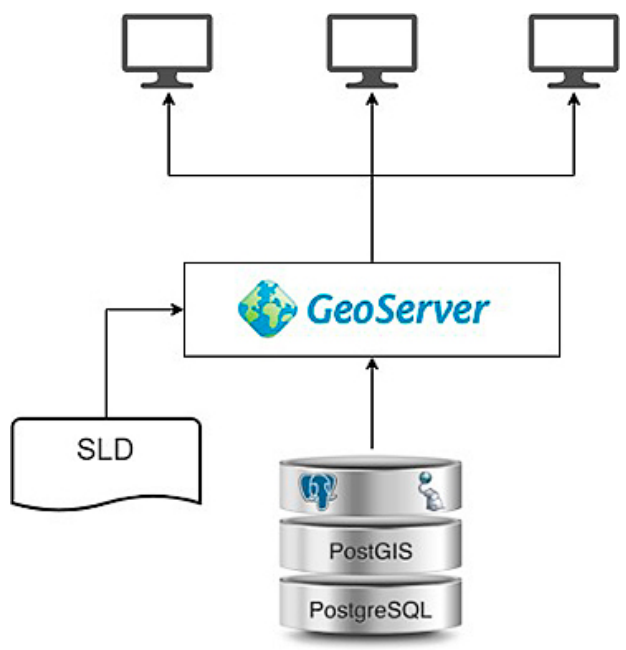

Figure 7. Three-layer architecture

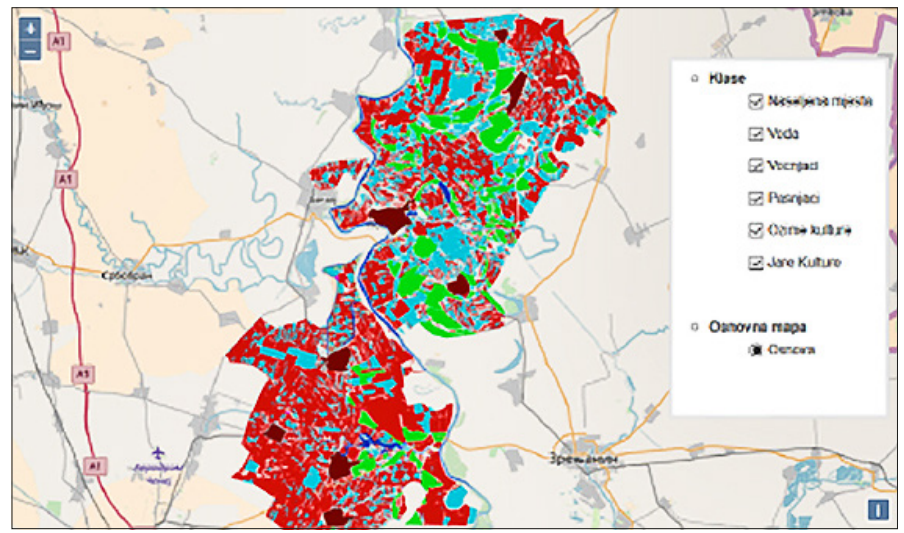

Figure 8. Data distribution through OpenLayers in 2D environment

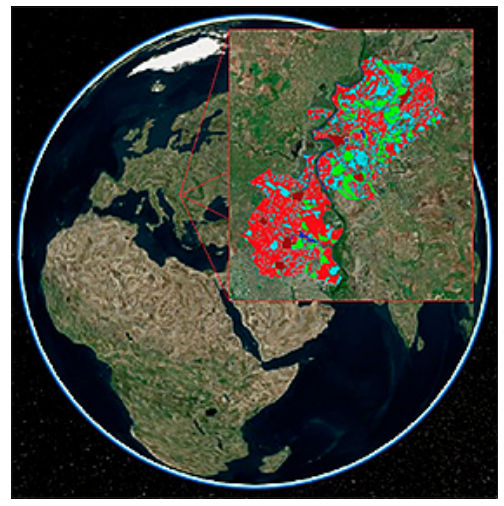

Figure 9. Data distribution through Cesium - a virtual globe 


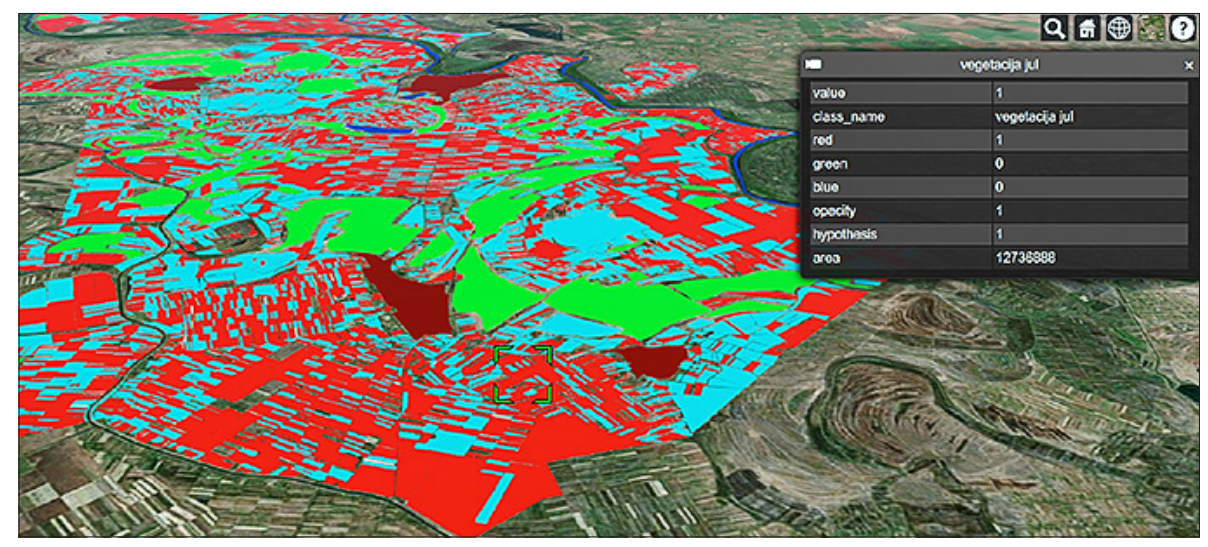

Figure 10. Reviewing basic information about the data through Cesium

\section{CONCLUSION}

This paper describes the method for arable land identification using satellite images from the Sentinel-2 platform for the area of municipalities of Novi Becej and Žabalj, as well as the presentation and distribution of the obtained data through the GIS threelayer service-oriented architecture. In order to ensure higher accuracy of the results, atmospheric correction was performed on the images using the dark object substraction method to eliminate the effect of the atmosphere, which is the key step in analyzes based on temporal image comparison. After data preprocessing, the SAVI vegetation index was used to enhance the vegetation signal. SAVI was chosen because arable lands, in most cases, are annual crops, and SAVI can eliminate soil reflectance. Winter and summer crops identification was based on known annual crops land cover variations, raster classification and raster subtraction process. Because this method produces rough results with certain amount of errors, data was vectorized and manually corrected. Since there is no automatic identification method for orchards, vineyards and pastures, those areas were manually identified with images from different acquisition periods. The final results were 7 vector files representing 7 classes: summer crops, winter crops, orchards and vineyard, pastures, places, water surfaces and unidentified land.

Advantages of used method certainly are: speed, availability of data and necessary resources, obtaining georeferenced data and good results for annual crops. It should be noted that the identification method can be applied to any geographical area, not just for the territory of Serbia. The results are loaded into a spatial database and displayed through the service-oriented architecture on the geoportal. 


\section{REFERENCES}

Chen, C., Liu, C. i Zhang S. (2012). Atmospheric correction of remote sensing imagery based on the surface spectrum's vector space. Science China Earth Sciences, 55, 12891296.

Drusch, M., Del Bello, U., Carlier, S., Colin, O., Fernandez, V., Gascon, F., Hoersch, B., Isola, C., Laberinti, P., Martimort, P., i ostali. (2012). Sentinel-2: ESA's Optical HighResolution Mission for GMES Operational Services. Remote Sensing of Environment, $120,25-36$.

Huete, A.R., (1988). A soil-adjusted vegetation index (SAVI). Remote Sensing of Environment, 25, 295-309

Jovanović, D., Govedarica M., Sabo F., Važić R. i Popović D., (2016). Impact analysis of pansharpening Landsat ETM+, Landsat OLI, WorldView-2, and Ikonos images on vegetation indices. Fourth International Conference on Remote Sensing and Geoinformation of the Environment (RSCy2016). Cyprus

Pat S., Chavez Jr. (1988). An improved dark-object subtraction technique for atmospheric scattering correction of multispectral data. Remote Sensing of Environment, 24, 459-479

Regodić, M. (2008). Daljinska detekcija kao metod prikupljanja podataka o prostoru. Vojnotehnički glasnik, 56, 91-112

Sladić, D., Radulović, A., Govedarica M., (2014). Application of service oriented GIS in agriculture. Research Journal of Agricultural Science, 46 (3), 2014

Xiaolin, L, (2005). An investigation on service-oriented architecture for constructing distributed Web GIS application. IEEE International Conference on Services Computing (SCC'05) Vol-1. USA, Florida, Orlando 